\title{
NATIONALISMS VERSUS SOLIDARITY IN CASE OF EU LAW AND SECURITY
}

\author{
Nikolay MARIN \\ "Neofit Rilski" South-West University, Blagoevgrad, Bulgaria \\ marin@law.swu.bg
}

\begin{abstract}
The purpose of this article is to focus on the main prerequisites for the increasing nationalism among some of the Member States in the European Union and its impact in terms of solidarity, law, and security. In recent years, a number of events and processes have unlocked the growth of nationalism and the increase of its public support as a response to the fear of replacing the values and identity of European societies. For example, the disproportionate migratory pressures "woke up" in some European societies a legitimate fear for their national identity. It is now the time to offer legal mechanisms that are flexible enough for sharing security and finding a balance between the national and European interest in order to avoid a revival of extreme nationalism.
\end{abstract}

Keywords: nationalism, solidarity, migratory pressure, EU law and security

\section{Introduction}

The migratory and refugee crisis on the territory of the Member States of the European Union, especially since the peak reached in 2015, has significantly changed the existing agenda of both the EU institutions and the Member States at a domestic level. European countries face major legal and political problems, some of which face basic principles and values of the process of European integration. The increasing nationalism, strongly expressed in some Member States, is increasingly beginning to contradict the EU solidarity principle - one of the founding values upon which the EU is built.

\section{Nationalism and solidarity among EU} Member States - a contradiction among them or opportunities for interaction

The concern about the instability of the migration crisis as a result of the entry into the EU of both persons in need of protection and of illegal migrants is quite justified. The European Union is an atypical subject of international law and as such has succeeded in establishing itself as an organization that protects human rights in the most reliable and effective way. At present, however, there is a lack of synergy between EU law and the provision of a security policy and protection of the rights of European citizens. The findings on the shortcomings of the EU's functioning mechanisms relate to the qualitatively new developments occurring in the EU's neighborhood and the inadequate legal framework that is not sufficiently clear and goes against the interests of the EU itself, in particular, most of the Member States. [1] Why is the current moment different from any similar migratory problems from previous periods? Since ancient times migration and migration of peoples has always existed and will exist. The previous moment when the EU faces challenges in regulating the migration crisis is in the collapse of the former Yugoslavia, when 
millions of citizens, fearing their own and the lives of their loved ones, have begun to seek asylum in Western Europe. This was a figurative "internal migration" within the European Community that did not cause such fears and fears about the national identity and EU internal security. A basic prerequisite for a significant increase in migratory pressure is both external and internal processes. One of them is the increase in free movement within the EU as a result of the abolition of border controls in the Schengen area based on the need for interaction, but with individual migration rather than mass, which makes Italy, Greece and all Member States that are the EU's external border the most vulnerable states. At some point, the migration wave is testing the national identity in countries that are subject to strong pressure from numerous groups of people with a different legal status, both under international refugee and migration law as well as EU law. All this provokes and stimulates the conditions for an increase of nationalism so that a society could emphatically express its belonging to established founding values. One of the possible solutions for securing the national identity of states is to develop reliable legal mechanisms for their preservation. Although it is precisely the national identity contained in primary EU law, we think it is good to develop more effective legal mechanisms, including at EU level, because this is one of the issues that is sensitive but relevant to the overall process of integration and its dynamically changing goals for shaping the EU. [2]

At the same time, some of the root causes of the growing migration to Europe over the recent decades are political controversies and military conflicts in the Middle East, resulting in sophisticated forms of crimes such as terrorism, cybercrime, human trafficking, arms and drugs. In this sense, the migration crisis has led to a significant increase not only in criminal activities in the territory of the affected Member States but also in a cross-border organized crime.
Thus, the right of sovereign states to administer justice in accordance with their national law is bound by the obligation to observe international principles, in particular with the rules of EU law, in the field of criminal justice: "The $\mathrm{Ne}$ bis in idem principle has to comply with the mandatory prosecution principle, which is an expression of the sovereignty and which the countries could hardly give up." [3] The duplication of criminal jurisdictions often creates "conflicts of competence", the resolution for which the European legislator has already endorsed a number of legal mechanisms as an extradition, transfer of criminal proceedings, transfer of sentenced persons, recognition and enforcement of foreign judgments, etc. [4] These forms of legal cooperation between European countries aim to balance the national and supranational interests in favor of a higher value, such as the rule of law. Nevertheless, the issue of national identity remains on the agenda.

As mentioned above, in the current situation, EU citizens are facing a highly complex migration crisis that raises legitimate fears. [5] The latter one has the effect of increasing sensitivity on topics such as radical nationalism that needs to be mastered. At the same time, however, account should be taken of the concerns of EU citizens about the change and deletion of their identity, for which there are obvious preconditions. One of these prerequisites is the difference in value systems between the citizens of the respective state and the migrants, which inevitably leads to conflicts based on incompatibility of values: "The latter finds an expression in the diversity, concerning the understanding of good - evil, fair unfair, sin, status of genders in society and others, which are arising from specifics of the different cultures that honor different values". [6]

There is no doubt that the migration crisis and its consequences are not suffered equally and jointly by the Member States, 
as there are countries which, given their geographical situation, are the first and most affected. [7] If the philosophy of functioning of the current Dublin system, which is a set of acts - part of the secondary EU legislation is kept, this will lead to the destabilization of the first countries through which illegal migrants have migrated. A separate problem is the fact that countries with a better standard of living are preferred, so that in Germany, which is the most developed Member State in economic terms, there are more than one million migrants and refugees. The present system of migrant displacement was categorically rejected by the Visegrad Group (Poland, the Czech Republic, Hungary and Slovakia). [8]

3. Possible solutions to address the consequences of migratory disproportionate pressures supporting solidarity and stability in the EU. Conclusions and guidelines for the optimization of the cooperation under the conditions of migration and terrorist activity

Decisions to tackle the effects of migratory pressure are one of the key issues as they require the involvement of different approaches and areas of European integration. At the legal and policy level, these are the following measures which, after their implementation, can develop a conceptual solution that could be applied in other subsequent crises, namely:

- A comprehensive overview of the Schengen legal system and the Schengen acquis in the new external and internal security conditions in the EU;

- Choice of options for strengthening external borders or periodic but at the same time flexible control of internal border controls;

- Searching for new forms of police cooperation with countries that are external borders of the EU, following the example of the European Border and Coast Guard Agency, which started in Bulgaria in October 2016;

- New forms of police intelligence (presence) in regions generating challenges for the Schengen system and free movement in the EU;

- A decisive reduction in the administrative burden and the facilitation and simplification of police cooperation within the EU and Schengen. It is necessary to improve the model of operational rather than institutional cooperation; more direct contacts between employees, fewer permissions, and conditions;

- Creating a new SIS that integrates knowledge about all types of threats, including hybrid, terrorist, military, from outside sources and contacts with all EU security systems (satellite, military, economic, diplomatic). This is also the major objective of the Integrated Border Management System. It is happening, but it is necessary to speed up and overtake the network organization of threats.

\section{Conclusion}

The current stage is characterized by the need for a more focused look and analysis of the reasons for the increase of nationalism as a consequence of the fears of replacing national identity and values in European states. [9] Decisions on nationalism as a defense response and solidarity with regard to the various aspects of European integration - positive and negative - are at the heart of the future development of the EU. Balancing the interests of the Member States, especially those with a different attitude towards overcoming the effects of the migration crisis and further managing the processes related to the free movement of people, goods, capitals, and services, should be ensured by flexible and sufficiently effective legal instruments. 


\section{References}

[1] Mihaylov, G. National Law or EU Law, in a scientific collection „Economic, Social and Administrative Approaches to the Knowledge-Based Organization. Conference Proceedings 2“ (ISBN 978-973-153-274-5), Land Forces Academy "Nicolae Balchesku", Sibiu, Romania, 2017, pp. 187-191.

[2] Belova G., Georgieva G. A New Data Protection Development in The EU Judicial and Criminal Area, International conference KNOWLEDGE-BASED ORGANIZATION 2017, Volume 23, Issue 2, Pages 144-149, ISSN (Online) 2451-3113, ISSN (Print) 18436722, DOI: https://doi.org/10.1515/kbo-2017-0103.

[3] Voynova, R. Conflicts of Jurisdiction in Criminal Proceedings - Preconditions and Possible Solutions, in a scientific collection ,Economic, Social and Administrative Approaches to the Knowledge-Based Organization. Conference Proceedings 2", ISBN 978-973-153-274-5, Land Forces Academy "Nicolae Balchesku", Sibiu, Romania, 2017, pp. 227-232.

[4] Voynova, R. Comparison of the Transfer of Criminal Proceeding with Other Forms of International Legal Cooperation in Criminal Matters, in a scientific collection "The complex physiognomy of the International security environment", ISBN 978-973-153215-8, Land Forces Academy "Nicolae Balchesku", Sibiu, Romania, 2015, pp. 178-186.

[5] Belova, G. Rights and Freedoms of Non-Citizens in International Law, Conference Proceedings 2: Economic, Social and Administrative Approaches to the KnowledgeBased Organization", "Nicolae Bălcescu" Land Forces Academy Publishing House, SIBIU, Romania, 2014, pp. 393-398. ISSN 1843-6722.

[6] Stanin, M. The contemporary countries in the conditions of migratory multiculturalism, in a scientific collection „Economic, Social and Administrative Approaches to the Knowledge-Based Organization. Conference Proceedings 2“ (ISBN 978-973-153-274-5), Land Forces Academy "Nicolae Balchesku", Sibiu, Romania, 2017, pp. 201-205.

[7] Marin, N. Disproportionate Migration Pressure as a Challenge for the National Security of the Republic of Bulgaria, in a scientific collection "Economic, Social and Administrative Approaches to the Knowledge - based Organization. Conference Proceedings 2", Land Forces Academy "Nicolae Balchesku", Sibiu, Romania, 2016, p.134.

[8] Ivanova, D. Migrant crisis and the Visegrád Group `s Policy. In: The 22nd International Conference The Knowledge-Based Organization. Management and Military sciences. Conference Proceedings 1, 9-11 June 2016, (ISBN 978-973-153-245-5; ISSN 1843682X) "Nicolae Bălcescu" Land Forces Academy Publishing House, Sibiu, Romania, 2016, pp. 41-45.

[9] Belova G., Hristova A. Some Problems Related to the 'Human Embryo' in the European Union Law, International conference KNOWLEDGE-BASED ORGANIZATION 2016, Volume 22, Issue 2, Pages 292-297, ISSN (Online) 24513113, DOI: https://doi.org/10.1515/kbo-2016-0050. 